\title{
COMMENTARY
}

\section{The CCN family: a new stimulus package}

\author{
D R Brigstock ${ }^{1,2,3,4}$ \\ ${ }^{1}$ Department of Surgery, The Ohio State University, Columbus, Ohio 43212, USA \\ ${ }^{2}$ Department of Molecular and Cellular Biochemistry, The Ohio State University, Columbus, Ohio 43212, USA \\ ${ }^{3}$ Molecular, Cellular and Developmental Biology Program, The Ohio State University, Columbus, Ohio 43212, USA \\ ${ }^{4}$ Center for Cell and Vascular Biology, Children's Research Institute, Columbus, Ohio 43205, USA \\ (Requests for offprints should be addressed to D R Brigstock, Children's Research Institute, 700 Children's Drive, Columbus, Ohio 43205, USA; \\ Email: brigstod@pediatrics.ohio-state.edu)
}

\begin{abstract}
The CCN family comprises cysteine-rich 61 (CYR61/ CCN1), connective tissue growth factor (CTGF/CCN2), nephroblastoma overexpressed (NOV/CCN3), and Wntinduced secreted proteins-1 (WISP-1/CCN4), -2 (WISP$2 / \mathrm{CCN} 5)$ and -3 (WISP-3/CCN6). These proteins stimulate mitosis, adhesion, apoptosis, extracellular matrix production, growth arrest and migration of multiple cell types. Many of these activities probably occur through the ability of CCN proteins to bind and activate cell surface
\end{abstract}

integrins. Accumulating evidence supports a role for these factors in endocrine pathways and endocrine-related processes. To illustrate the broad role played by the CCN family in basic and clinical endocrinology, this article highlights the relationship between CCN proteins and hormone action, skeletal growth, placental angiogenesis, IGF-binding proteins and diabetes-induced fibrosis.

Journal of Endocrinology (2003) 178, 169-175

\section{Introduction}

Over the last few years, articles on members of the new 'CCN' family - which includes cysteine-rich 61 (CYR61/CCN1), connective tissue growth factor (CTGF/CCN2), nephroblastoma overexpressed (NOV/ CCN3), and Wnt-induced secreted proteins-1 (WISP-1/ CCN4), -2 (WISP-2/CCN5) and -3 (WISP-3/CCN6) have started to be published in this and other endocrinology journals. This trend reflects the finding that a variety of endocrine functions are impacted directly and indirectly by individual CCN proteins and that they probably are important modulators of hormonal pathways and hormonally regulated processes.

Originally discovered in the early to mid 1990s, members of the CCN family are $30-40 \mathrm{kDa}$ proteins that are extremely cysteine-rich (10\% by mass) (Brigstock 1999, Lau \& Lam 1999, Perbal 2001). Collectively, these proteins stimulate mitosis, adhesion, apoptosis, extracellular matrix (ECM) production, growth arrest and migration, and regulate angiogenesis, tumor growth, placentation, implantation, embryogenesis and endochondral ossification. Target cells include fibroblasts, epithelial cells, endothelial cells, smooth muscle cells and neuronal cells (Moussad \& Brigstock 2000). One of the most important features of CCN proteins - yet one of the least understood - is that they are multi-modular mosaic proteins containing four conserved modules which are present in other unrelated extracellular proteins (Bork 1993, Brigstock 1999, Lau \& Lam 1999, Perbal 2001). Module 1 is an insulin-like growth factor (IGF)-binding domain, module 2 is a von Willebrand type $\mathrm{C}$ domain, module 3 is a thrombospondin- 1 domain, and module 4 is a C-terminal domain containing a putative cystine knot (Fig. 1). CCN proteins may exhibit biological activities that are consistent with the known properties of each constituent module, although data have started to emerge showing that certain modules can also act inter-dependently. The modular configuration may not only dictate direct actions of CCN proteins on target cells, but also their bioavailability, half-life, binding of other protein moieties, and regulation in time and space (Bork 1993, Brigstock 1999, Perbal 2001). Diversity in CCN functions may arise due to structural heterogeneity in the modular configuration. For example module 4 is absent in WISP-2/CCN5 (Pennica et al. 1998, Zhang et al. 1998) and modules 1-3 are absent in products of CTGF/CCN2 proteolysis (Brigstock et al. 1997, Ball et al. 1998).

The underlying mechanisms of action of $\mathrm{CCN}$ proteins have proven elusive, perhaps because the earlier (and 


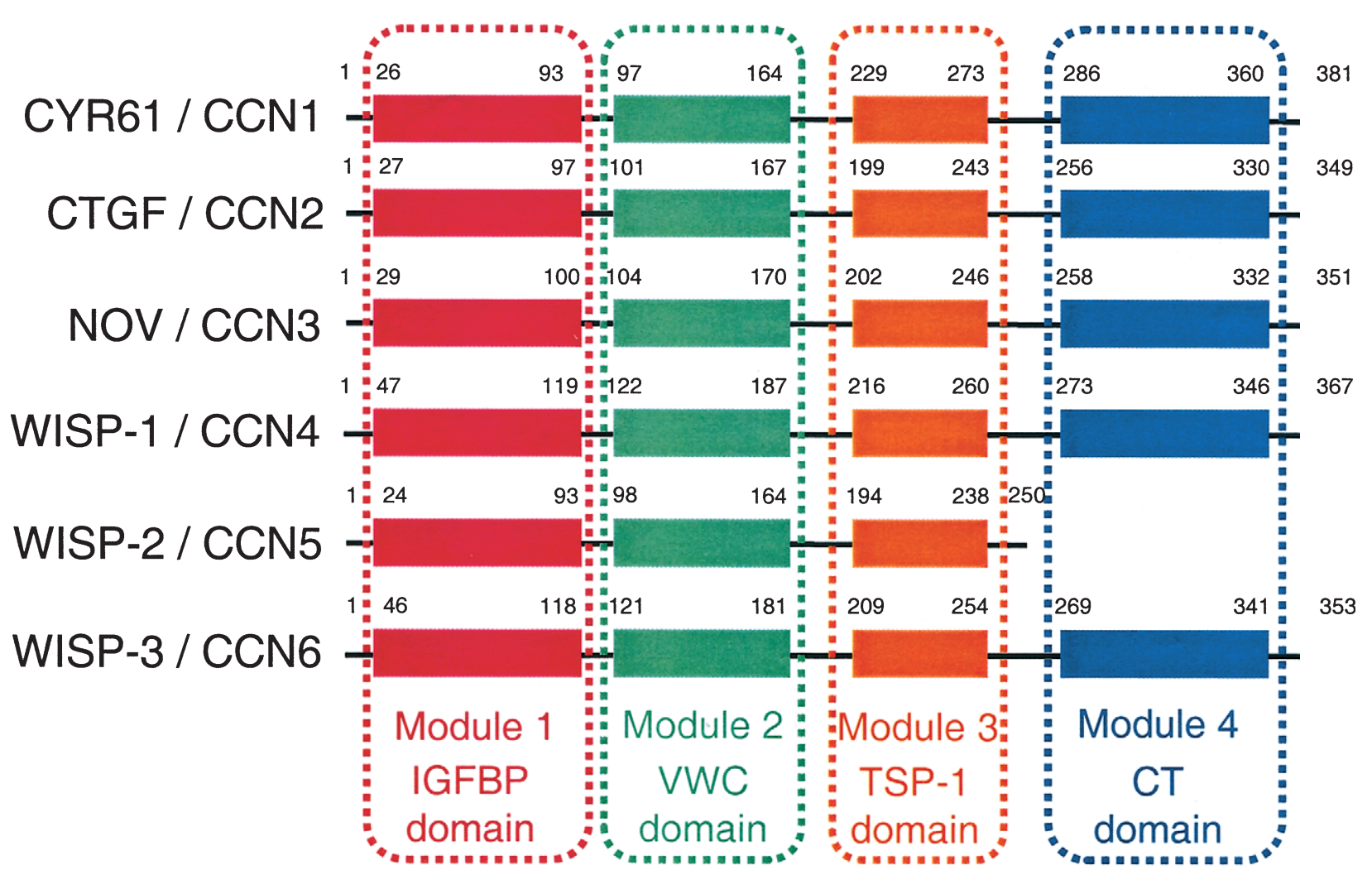

Figure 1 Modular structure of the CCN protein family. Residues are numbered according to the human orthologs of each protein. Amino acid sequences within individual modules are conserved 38-98\%. There is absolute conservation of 38 cysteine residues except in WISP-1/CCN4, which lacks four cysteines in module 2. Note the absence of module 4 in WISP-2/CCN5. Bioactive forms of CTGF/CCN2 lacking modules 1 and 2 or $1-3$ and of NOV/CCN3 lacking module 1 have been reported. There are 25- to 30-residue signal peptide sequences preceding module 1 in each protein.

naive) view was that they acted in a similar fashion to classic growth factors. Attempts to identify unique specific high-affinity signal-transducing receptors have been fruitless. It is now felt that these molecules may act as matricellular proteins that bridge the functional and physical gap between ECM-associated proteins and cell surface molecules (Lau \& Lam 1999). Recent data have shown that CYR61/CCN1, CTGF/CCN2 and NOV/CCN3 bind to cell surface integrins and thereby induce intracellular signaling events that include kinase activation and gene transcription (Lau \& Lam 1999, C C Chen et al. 2000, 2001, N Chen et al. 2000, Grzeszkiewicz et al. 2001, 2002, Leu et al. 2002, Schober et al. 2002). Additionally, CCN proteins exhibit strong affinity for heparin and are localized on cell surfaces or in ECM in association with heparan sulfate proteoglycans (HSPGs). The diverse biological functions of CCN proteins may reside in the unique interactions of individual $\mathrm{CCN}$ proteins with specific integrin subtypes expressed by a given target cell, the utilization of cell surface HSPGs as co-receptors, and the cross talk of these binding moieties with other signaling molecules such as growth factor receptors.
Below, I briefly summarize five aspects of CCN biology that are of interest to endocrinologists. While this list is not exhaustive, it serves to highlight the broad and versatile endocrinological aspects of this new gene family. A conceptual framework is presented in Fig. 2.

\section{Hormone action}

CYR61/CCN1 and CTGF/CCN2 are both estrogeninducible and overexpressed in steroid-dependent breast or uterine tumors (Tsai et al. 2000, 2002b. Sampath et al. 2001a,b, 2002, Xie et al. 2001a,b). CYR61/CCN1 promotes breast cancer progression and is associated with more advanced disease (Xie et al. 2001a, Tsai et al. 2002a). Proliferation of breast cancer cell lines in vitro is antagonized by anti-CYR61/CCN1 antibodies and the production of CYR61/CCN1 by these cells is antagonized by anti-estrogens (Sampath et al. 2001a, Tsai et al. 2002b). WISP-2/CCN5 is also induced by estrogen in breast cancer cells (Inadera et al. 2000, 2002). Antiprogestins are effective in antagonizing CYR61/CCN1 


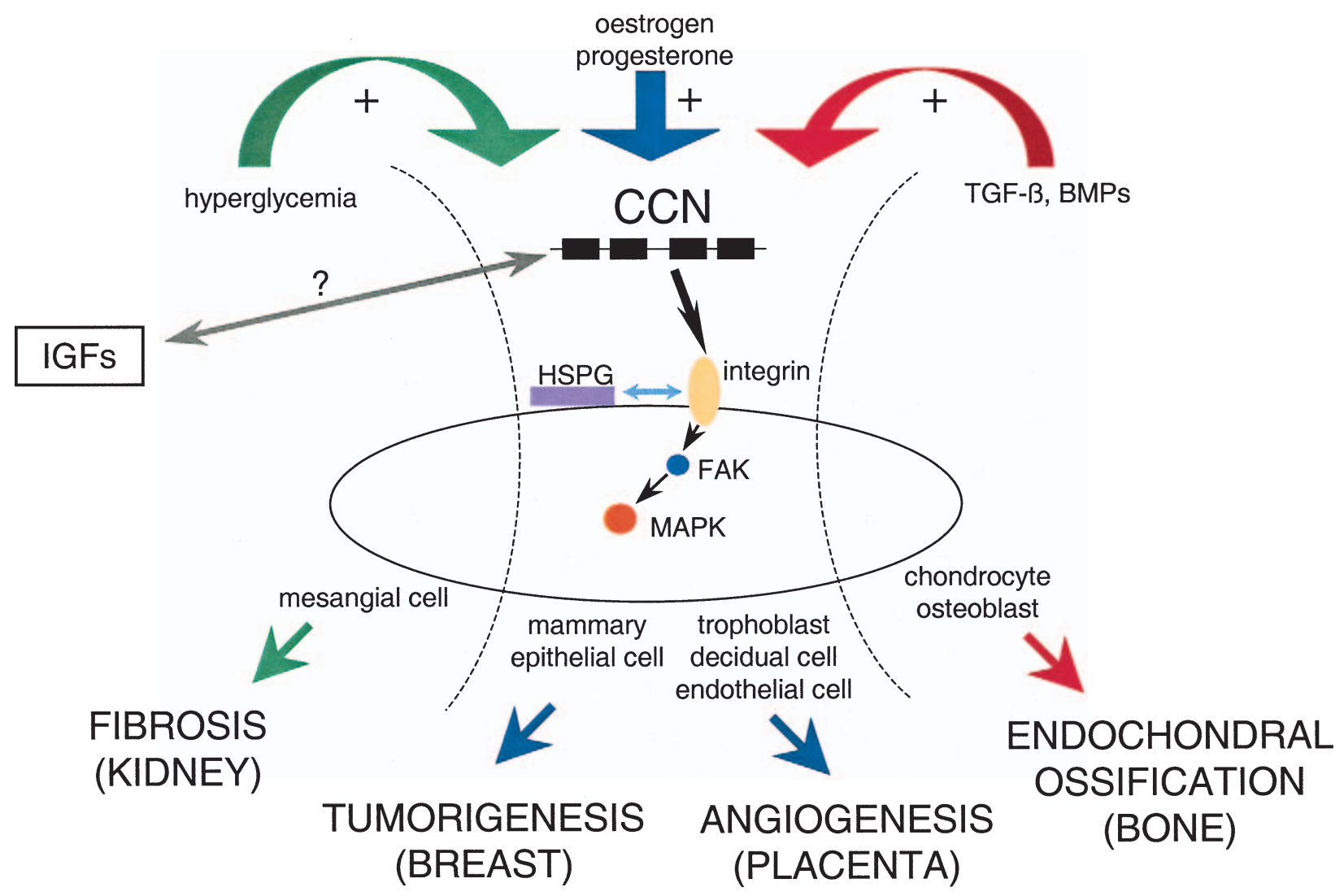

Figure 2 Key pathways of $\mathrm{CCN}$ protein regulation and function. Some of the major pathways of CCN action described in the text are shown. Note that evidence for $\mathrm{CCN}$ protein interactions on cell surfaces has not been verified for all cell types depicted nor for all $\mathrm{CCN}$ proteins. To date, activation of focal adhesion kinase (FAK) and mitogen-activated kinase (MAPK) have been demonstrated principally in fibroblasts or endothelial cells treated with CYR61/CCN1, CTGF/CCN2 or NOV/CCN3. TGF- $\beta$, transforming growth factor-beta; BMPs, bone morphogenetic proteins.

production by breast cancer cells (Sampath et al. 2002). Collectively, these data point to the CCN family members as important downstream mediators of estrogen- and progesterone-regulated cell growth. However, CCN proteins may also impact other growth regulatory pathways in breast cancer cells. WISP-3/CCN6, for example, is a tumor suppressor that exhibits reduced expression in inflammatory breast cancer (Kleer et al. 2002).

In addition to their roles in steroid-dependent tumor growth, CCN proteins are involved as downstream mediators of normal physiological hormone action in organs such as the uterus or ovary. Uterine CTGF/CCN2 is regulated by both estrogen and progesterone and appears to be important for maintenance or remodeling of stromal ECM (Rageh et al. 2001, Cheon et al. 2002). In the ovary, CTGF/CCN2 production is regulated by gonadotropins or transforming growth factor-beta (TGF- $\beta$ ) and is associated with thecal cell recruitment and mitosis, and maintenance of the corpus luteum (Wandji et al. 2000, Slee et al. 2001, Harlow \& Hillier 2002, Harlow et al. 2002, Liu et al. 2002).

\section{Skeletal growth}

CTGF/CCN2 has emerged as an important player in chondrogenesis and endochondral ossification as shown by its ability to promote proliferation, maturation and hypertrophy of cultured growth or articular cartilage cells (Takigawa et al. 2003). During embryogenesis, CTGF/ CCN2 is expressed in zones containing hypertrophic chondroctyes or calcifying cartilage of long bones, ribs, vertebral column and phalanges. It is also produced by osteoblasts in primary spongiosa and ameloblasts or odontoblasts in incisal teeth (Takigawa et al. 2003). CTGF/CCN2 is expressed in hypertrophic chondrocytes, proliferating chondrocytes and proliferating periosteal cells during healing of fractured ribs (Nakata et al. 2002). During limb regeneration in newts, the expression of CTGF/CCN2 is consistent with a role in osteoclast production and endochondral ossification of the hypertrophied cartilaginous limb skeleton (Cash et al. 1998).

In vitro, CTGF/CCN2 promotes chondroctye cell growth and hypertrophy, as well as increased expression of 
proteoglycans, aggrecan and collagens (Nakanishi et al. 2000, Nishida et al. 2000, 2002). CTGF/CCN2 levels in skeletal cells are stimulated by TGF- $\beta$ and bone morphogenic protein-2, consistent with the known role of these proteins in skeletal growth as well as the observation that CTGF/CCN2 is an immediate early gene for TGF- $\beta$ (Nakanishi et al. 1997). Finally, CTGF/CCN2-null mice demonstrate multiple skeletal defects including expanded hypertrophic zones of long bones, possibly due to decreases in growth plate angiogenesis, chondrocyte proliferation and matrix-degrading enzymes. (Ivkovic et al. 2003).

CYR61/CCN1 promotes collagen and cartilage production in limb bud micromass cultures and stimulates chondrogenesis, mitogenesis and adhesion in limb mesenchymal cells (O’Brien \& Lau 1992, Wong et al. 1997). CYR61/CCN1 production in fetal osteoblasts is regulated by vitamin D3 (Schutze et al. 1998) while NOV/CCN3 is involved in calcium signaling (Li et al. 2002), which may pertain to a role in bone metabolism. Mutations in the WISP-3/CCN6 gene are associated with progressive pseudorheumatoid dysplasia, an autosomal recessive skeletal disorder characterized by continued cartilage loss and bone destruction (Hurvitz et al. 1999). WISP-3/ CCN6-null mice have more mature vertebral endplates, a phenomenon that may be due to accelerated endochondral ossification (see Perbal et al. 2003).

\section{Placental angiogenesis}

Production of CTGF/CCN2 by mouse uterine stromal cells increases dramatically as the cells differentiate into decidual cells following implantation (Surveyor et al. 1998). At later stages, CYR61/CCN1 and CTGF/CCN2 are present in trophoblast giant cells (Kireeva et al. 1997). In the non-invasive placenta of the pig, CTGF/CCN2 production by uterine epithelium is markedly reduced during the attachment phase and may facilitate subepithelial matrix reorganization and angiogenesis (Moussad et al. 2002). Thereafter many cells in the utero-placental unit produce high levels of CTGF/CCN2, which may promote matrix stabilization and angiogenesis within it. An essential role for CYR61/CCN1 during embryogenesis has recently been shown in knockout mice, which failed to develop in utero due to vascular defects in the placenta (Mo et al. 2002). The defect appeared to be related to the inability of new capillaries to bifurcate, suggesting that CYR61/CCN1 facilitates the development of a branching capillary network. Indeed, the ability of CYR61/CCN1 and CTGF/CCN2 to regulate endothelial cell proliferation and angiogenesis is well established (Brigstock 2002). Recently, NOV/CCN3 was shown to be angiogenic (Lin et al. 2003), although WISP-3/CCN6 appears to be anti-angiogenic (Perbal et al. 2003).

\section{IGF binding}

Module 1 exhibits similarity to IGF-binding proteins (IGFBPs) and speculation has arisen regarding a role for CCN proteins in IGF transport and delivery (Bork 1993, Kim et al. 1997, Burren et al. 1999). However, rather than exhibiting the high-affinity IGF binding $\left(K_{\mathrm{d}}=10^{-10}\right.$ $10^{-11} \mathrm{M}$ ) that is characteristic of IGFBP-1 to -6 , the binding affinity of CCN proteins for IGFs is 2 or 3 orders of magnitude less. While IGF binding in vitro has been reported for CTGF/CCN2, NOV/CCN3 and WISP-3/ CCN6 (Kim et al. 1997, Burren et al. 1999, Kleer et al. 2003), this interaction has not been definitively attributed to sequences in module 1 and classic IGF ligand blots with NOV/CCN3 proved unsuccessful (Chevalier et al. 1998). Although investigators have proposed that the CCN family is part of an IGFBP superfamily (Kim et al. 1997, Baxter et al. 1998, Rosenfeld 2001), the physiological importance of CCN-IGF interactions will remain controversial until the appropriate experiments are performed (Collet \& Candy 1998, Grotendorst et al. 2000). It is noteworthy that some CTGF/CCN2 isoforms are active in the complete absence of module 1 (Brigstock et al. 1997, Ball et al. 1998), although a regulatory role of module 1 on these actions cannot be formally excluded. Interestingly, the IGF-binding property of WISP-3/CCN6 has been linked to IGF signaling in inflammatory breast cancer (Kleer et al. 2003).

\section{Diabetes-induced fibrosis}

Diabetes mellitus type 1 leads to fibrotic pathology in multiple organs including the kidney, arteries and heart. In early stages of diabetic nephropathy, high glucose levels are associated with mesangial cell hypertrophy and matrix production and this effect is mimicked by exogenous stimulation with CTGF/CCN2 (Riser et al. 2000, Wahab et al. 2002). In addition, high glucose conditions, TGF- $\beta$, mechanical strain or CTGF/CCN2 itself promote CTGF/ CCN2 expression by mesangial cells (Wahab et al. 1996, Murphy et al. 1999, Riser et al. 2000). As in other fibrotic diseases, CTGF/CCN2 acts downstream of TGF- $\beta$ and has been linked to chronic tubulointerstitial fibrosis (Wang et al. 2001, Yokoi et al. 2001, 2002) suggesting that $\mathrm{CTGF} / \mathrm{CCN} 2$ may be a novel therapeutic target in renal fibrosis (Crean et al. 2001). CTGF/CCN2 expression is inhibited in the diabetic kidney by aminoguanidine, an inhibitor of advanced glycosylation end products (AGEs), which are pro-fibrotic and cause induction of CTGF/ CCN2 and fibronectin (Twigg et al. 2001, 2002a,b). CTGF/CCN2 levels are also elevated in diabetes-induced cardiac fibrosis and atherosclerosis and these can be inhibited by, respectively, inhibitors of either AGE or angiotensin-converting enzyme (Candido et al. 2002, 2003, Way et al. 2002). 


\section{Concluding comments}

Although this article has focused on endocrinological aspects, research into all areas of the CCN family continues to gain pace. In the next few years, we can expect to learn much more about aspects of CCN structurefunction as well as more detailed studies of the production, regulation and action of CCN molecules in normal and diseased tissues. There is guarded optimism that at least some of these factors will have useful prognostic or diagnostic applications and that some may even be viable therapeutic targets. In the current era of gene-array technology, we can anticipate that $\mathrm{CCN}$ proteins will be implicated in additional endocrine-related processes and that new functions for $\mathrm{CCN}$ proteins will be unraveled.

\section{Acknowledgements}

D R B is funded by NIH grant AA12817-02.

\section{References}

Ball DK, Surveyor GA, Diehl JR, Steffen CL, Uzumcu M, Mirando MA \& Brigstock DR 1998 Characterization of 16- to 20-kilodalton (kDa) connective tissue growth factors (CTGFs) and demonstration of proteolytic activity for $38-\mathrm{kDa}$ CTGF in pig uterine luminal flushings. Biology of Reproduction 59 828-835.

Baxter RC, Binoux MA, Clemmons DR, Conover CA, Drop SL, Holly JM, Mohan S, Oh Y \& Rosenfeld RG 1998

Recommendations for nomenclature of the insulin-like growth factor binding protein superfamily. Endocrinology 1394036.

Bork P 1993 The modular architecture of a new family of growth regulators related to connective tissue growth factor. FEBS Letters 327 125-130.

Brigstock DR 1999 The connective tissue growth factor/cysteine-rich 61/nephroblastoma overexpressed (CCN) family. Endocrine Reviews 20 189-206.

Brigstock DR 2003 Regulation of angiogenesis and endothelial cell function by connective tissue growth factor (CTGF) and cysteine-rich 61 (CYR61). Angiogenesis 5 153-165.

Brigstock DR, Steffen CL, Kim GY, Vegunta RK, Diehl JR \& Harding PA 1997 Purification and characterization of novel heparin-binding growth factors in uterine secretory fluids. Identification as heparin-regulated $\mathrm{Mr} 10000$ forms of connective tissue growth factor. Journal of Biological Chemistry 272 20275-20282.

Burren CP, Wilson EM, Hwa V, Oh Y \& Rosenfeld RG 1999 Binding properties and distribution of insulin-like growth factor binding protein-related protein 3 (IGFBP-rP3/NovH), an additional member of the IGFBP Superfamily. Journal of Clinical Endocrinology and Metabolism 84 1096-1103.

Candido R, Jandeleit-Dahm KA, Cao Z, Nesteroff SP, Burns WC, Twigg SM, Dilley RJ, Cooper ME \& Allen TJ 2002 Prevention of accelerated atherosclerosis by angiotensin-converting enzyme inhibition in diabetic apolipoprotein E-deficient mice. Circulation $106246-253$

Candido R, Forbes JM, Thomas MC, Thallas V, Dean RG, Burns WC, Tikellis C, Ritchie RH, Twigg SM, Cooper ME et al. 2003 A breaker of advanced glycation end products attenuates diabetes-induced myocardial structural changes. Circulation Research $92785-792$.
Cash DE, Gates PB, Imokawa Y \& Brockes JP 1998 Identification of newt connective tissue growth factor as a target of retinoid regulation in limb blastemal cells. Gene 222 119-124.

Chen CC, Chen N \& Lau LF 2000 The angiogenic factors Cyr61 and CTGF induce adhesive signaling in primary human skin fibroblasts. Journal of Biological Chemistry 276 10443-10452.

Chen CC, Mo FE \& Lau LF 2001 The angiogenic factor Cyr61 activates a genetic program for wound healing in human skin fibroblasts. Journal of Biological Chemistry 276 47329-47337.

Chen N, Chen CC \& Lau LF 2000 Adhesion of human skin fibroblasts to Cyr61 is mediated through integrin alpha 6 beta 1 and cell surface heparan sulfate proteoglycans. Journal of Biological Chemistry 275 24953-24961.

Cheon YP, Li Q, Xu X, DeMayo FJ, Bagchi IC \& Bagchi MK 2002 A genomic approach to identify novel progesterone receptor regulated pathways in the uterus during implantation. Molecular Endocrinology 16 2853-2871.

Chevalier G, Yeger H, Martinerie C, Laurent M, Alami J, Schofield PN \& Perbal B 1998 novH: differential expression in developing kidney and Wilms' tumors. American Journal of Pathology 152 $1563-1575$.

Collet C \& Candy J 1998 How many insulin-like growth factor binding proteins? Molecular and Cellular Endocrinology 139 1-6.

Crean JK, Lappin D, Godson C \& Brady HR 2001 Connective tissue growth factor: an attractive therapeutic target in fibrotic renal disease. Expert Opinions in Therapeutic Targets 5 519-530.

Grotendorst GR, Lau LF \& Perbal B 2000 CCN proteins are distinct from and should not be considered members of the insulin-like growth factor-binding protein superfamily. Endocrinology 141 2254-2256.

Grzeszkiewicz TM, Kirschling DJ, Chen N \& Lau LF 2001 CYR61 stimulates human skin fibroblast migration through integrin alpha vbeta 5 and enhances mitogenesis through integrin alpha vbeta 3 , independent of its carboxyl-terminal domain. Journal of Biological Chemistry $27621943-21950$.

Grzeszkiewicz TM, Lindner V, Chen N, Lam SC \& Lau LF 2002 The angiogenic factor cysteine-rich 61 (CYR61, CCN1) supports vascular smooth muscle cell adhesion and stimulates chemotaxis through integrin alpha(6)beta(1) and cell surface heparan sulfate proteoglycans. Endocrinology 143 1441-1450.

Harlow CR \& Hillier SG 2002 Connective tissue growth factor in the ovarian paracrine system. Molecular and Cellular Endocrinology 187 23-27.

Harlow CR, Davidson L, Burns KH, Yan C, Matzuk MM \& Hillier SG 2002 FSH and TGF-beta superfamily members regulate granulosa cell connective tissue growth factor gene expression in vitro and in vivo. Endocrinology 143 3316-3325.

Hurvitz JR, Suwairi WM, Van Hul W, El-Shanti H, Superti-Furga A, Roudier J, Holderbaum D, Pauli RM, Herd JK, Van Hul EV et al. 1999 Mutations in the CCN gene family member WISP3 cause progressive pseudorheumatoid dysplasia. Nature Genetics $\mathbf{2 3}$ 94-98.

Inadera $\mathrm{H}$, Hashimoto S, Dong HY, Suzuki T, Nagai S, Yamashita T, Toyoda N \& Matsushima K 2000 WISP-2 as a novel estrogen-responsive gene in human breast cancer cells. Biochemical and Biophysical Research Communications 275 108-114.

Inadera H, Dong HY \& Matsushima K 2002 WISP-2 is a secreted protein and can be a marker of estrogen exposure in MCF-7 cells. Biochemical and Biophysical Research Communications 294 602-608.

Ivkovic S, Yoon BS, Popoff SN, Safadi FF, Libuda DE, Stephenson RC, Dailuski A \& Lyons KM 2003 Connective tissue growth factor coordinates chondrogenesis and angiogenesis during skeletal development. Development 130 2779-2791.

Kim HS, Nagalla SR, Oh Y, Wilson E, Roberts CT Jr \& Rosenfeld RG 1997 Identification of a family of low-affinity insulin-like growth factor binding proteins (IGFBPs): characterization of connective tissue growth factor as a member of the IGFBP superfamily. PNAS 94 12981-12986. 
Kireeva ML, Latinkic BV, Kolesnikova TV, Chen CC, Yang GP, Abler AS \& Lau LF 1997 Cyr61 and Fisp12 are both ECMassociated signaling molecules: activities, metabolism, and localization during development. Experimental Cell Research 233 63-77.

Kleer CG, Zhang Y, Pan Q, van Golen KL, Wu ZF, Livant D \& Merajver SD 2002 WISP3 is a novel tumor suppressor gene of inflammatory breast cancer. Oncogene 21 3172-3180.

Kleer CG, Zhang Y, Pan Q, Wu ZF \& Merajver SD 2003 WISP3, A tumor suppressor gene of inflammatory breast cancer binds to IGF-I and may modulate IGF signalling. Molecular Pathology 5668.

Lau LF \& Lam SC 1999 The CCN family of angiogenic regulators: the integrin connection. Experimental Cell Research 248 44-57.

Leu SJ, Lam SC \& Lau LF 2002 Pro-angiogenic activities of CYR61 (CCN1) mediated through integrins alphavbeta3 and alpha6 beta1 in human umbilical vein endothelial cells. Journal of Biological Chemistry 277 46248-46255.

Li CL, Martinez V, He B, Lombet A \& Perbal B 2002 A role for CCN3 (NOV) in calcium signalling. Molecular Pathology $\mathbf{5 5}$ 250-261.

Lin CG, Leu SJ, Chen N, Tebeau CM, Lin SX, Yeung CY \& Lau LF 2003 CCN3 (NOV) is a novel angiogenic regulator of the CCN protein family. Journal of Biological Chemistry 278 24200-24208.

Liu J, Kosma VM, Vanttinen T, Hyden-Granskog C \& Voutilainen R 2002 Gonadotrophins inhibit the expression of insulin-like growth factor binding protein-related protein-2 mRNA in cultured human granulosa-luteal cells. Molecular Human Reproduction 8 136-141.

Mo FE, Muntean AG, Chen CC, Stolz DB, Watkins SC \& Lau LF 2002 CYR61 (CCN1) is essential for placental development and vascular integrity. Molecular and Cellular Biology 22 8709-8720.

Moussad EE \& Brigstock DR 2000 Connective tissue growth factor: what's in a name? Molecular Genetics and Metabolism 71 276-292.

Moussad EE, Rageh MA, Wilson AK, Geisert RD \& Brigstock DR 2002 Temporal and spatial expression of connective tissue growth factor (CCN2; CTGF) and transforming growth factor beta type 1 (TGF-beta1) at the utero-placental interface during early pregnancy in the pig. Molecular Pathology 55 186-192.

Murphy M, Godson C, Cannon S, Kato S, Mackenzie HS, Martin F \& Brady HR 1999 Suppression subtractive hybridization identifies high glucose levels as a stimulus for expression of connective tissue growth factor and other genes in human mesangial cells. Journal of Biological Chemistry 274 5830-5834.

Nakanishi T, Kimura Y, Tamura T, Ichikawa H, Yamaai Y, Sugimoto T \& Takigawa M 1997 Cloning of a mRNA preferentially expressed in chondrocytes by differential display-PCR from a human chondrocytic cell line that is identical with connective tissue growth factor (CTGF) mRNA. Biochemical and Biophysical Research Communications 234 206-210.

Nakanishi T, Nishida T, Shimo T, Kobayashi K, Kubo T, Tamatani T, Tezuka K \& Takigawa M 2000 Effects of CTGF/Hcs24, a product of a hypertrophic chondrocyte-specific gene, on the proliferation and differentiation of chondrocytes in culture. Endocrinology 141 264-273.

Nakata E, Nakanishi T, Kawai A, Asaumi K, Yamaai T, Asano M, Nishida T, Mitani S, Inoue H \& Takigawa M 2002 Expression of connective tissue growth factor/hypertrophic chondrocyte-specific gene product 24 (CTGF/Hcs24) during fracture healing. Bone $\mathbf{3 1}$ 441-447.

Nishida T, Nakanishi T, Asano M, Shimo T \& Takigawa M 2000 Effects of CTGF/Hcs24, a hypertrophic chondrocyte-specific gene product, on the proliferation and differentiation of osteoblastic cells in vitro. Journal of Cellular Physiology 184 197-206.

Nishida T, Kubota S, Nakanishi T, Kuboki T, Yosimichi G, Kondo S \& Takigawa M 2002 CTGF/Hcs24, a hypertrophic chondrocytespecific gene product, stimulates proliferation and differentiation, but not hypertrophy of cultured articular chondrocytes. Journal of Cellular Physiology 192 55-63.
O'Brien TP \& Lau LF 1992 Expression of the growth factor-inducible immediate early gene cyr61 correlates with chondrogenesis during mouse embryonic development. Cell Growth and Differentiation 3 645-654.

Pennica D, Swanson TA, Welsh JW, Roy MA, Lawrence DA, Lee J, Brush J, Taneyhill LA, Deuel B, Lew M et al. 1998 WISP genes are members of the connective tissue growth factor family that are up-regulated in wnt-1-transformed cells and aberrantly expressed in human colon tumors. PNAS 95 14717-14722.

Perbal B 2001 NOV (nephroblastoma overexpressed) and the CCN family of genes: structural and functional issues. Molecular Pathology 54 57-79.

Perbal B, Brigstock DR \& Lau LF 2003 Report on the second international workshop on the CCN family of genes. Molecular Pathology 56 80-85.

Rageh MA, Moussad EE, Wilson AK \& Brigstock DR 2001 Steroidal regulation of connective tissue growth factor (CCN2; CTGF) synthesis in the mouse uterus. Molecular Pathology 54 338-346.

Riser BL, Denichilo M, Cortes P, Baker C, Grondin JM, Yee J \& Narins RG 2000 Regulation of connective tissue growth factor activity in cultured rat mesangial cells and its expression in experimental diabetic glomerulosclerosis. Journal of the American Society of Nephrology 11 25-38.

Rosenfeld R 2001 Nomenclature of the insulin-like growth factorbinding protein superfamily. Journal of Clinical Endocrinology and Metabolism 86946.

Sampath D, Winneker RC \& Zhang Z 2001a Cyr61, a member of the CCN family, is required for MCF-7 cell proliferation: regulation by 17 beta-estradiol and overexpression in human breast cancer. Endocrinology 142 2540-2548.

Sampath D, Zhu Y, Winneker RC \& Zhang Z $2001 b$ Aberrant expression of Cyr61, a member of the CCN (CTGF/Cyr61/Cef10/NOVH) family, and dysregulation by 17 beta-estradiol and basic fibroblast growth factor in human uterine leiomyomas. Journal of Clinical Endocrinology and Metabolism 86 $1707-1715$.

Sampath D, Winneker RC \& Zhang Z 2002 The angiogenic factor Cyr61 is induced by the progestin R5020 and is necessary for mammary adenocarcinoma cell growth. Endocrine 18 147-159.

Schober JM, Chen N, Grzeszkiewicz TM, Jovanovic I, Emeson EE, Ugarova TP, Ye RD, Lau LF \& Lam SC 2002 Identification of integrin alpha(M)beta(2) as an adhesion receptor on peripheral blood monocytes for Cyr61 (CCN1) and connective tissue growth factor (CCN2): immediate-early gene products expressed in atherosclerotic lesions. Blood 99 4457-4465.

Schutze N, Lechner A, Groll C, Siggelkow H, Hufner M, Kohrle J \& Jakob F 1998 The human analog of murine cystein rich protein 61 [correction of 16] is a 1 alpha,25-dihydroxyvitamin D3 responsive immediate early gene in human fetal osteoblasts: regulation by cytokines, growth factors, and serum. Endocrinology 139 1761-1770.

Slee RB, Hillier SG, Largue P, Harlow CR, Miele G \& Clinton M 2001 Differentiation-dependent expression of connective tissue growth factor and lysyl oxidase messenger ribonucleic acids in rat granulosa cells. Endocrinology 142 1082-1089.

Surveyor GA, Wilson AK \& Brigstock DR 1998 Localization of connective tissue growth factor during the period of embryo implantation in the mouse. Biology of Reproduction 59 1207-1213.

Takigawa M, Nakanishi T, Kubota S \& Nishida T 2003 Role of CTGF/HCS24/ecogenin in skeletal growth control. Journal of Cellular Physiology 194 256-266.

Tsai MS, Hornby AE, Lakins J \& Lupu R 2000 Expression and function of CYR61, an angiogenic factor, in breast cancer cell lines and tumor biopsies. Cancer Research 60 5603-5607.

Tsai MS, Bogart DF, Castaneda JM, Li P \& Lupu R 2002a Cyr61 promotes breast tumorigenesis and cancer progression. Oncogene $\mathbf{2 1}$ 8178-8185. 
Tsai MS, Bogart DF, Li P, Mehmi I \& Lupu R $2002 b$ Expression and regulation of Cyr61 in human breast cancer cell lines. Oncogene 21 964-973.

Twigg SM, Chen MM, Joly AH, Chakrapani SD, Tsubaki J, Kim HS, Oh Y \& Rosenfeld RG 2001 Advanced glycosylation end products up-regulate connective tissue growth factor (insulin-like growth factor-binding protein-related protein 2) in human fibroblasts: a potential mechanism for expansion of extracellular matrix in diabetes mellitus. Endocrinology 142 1760-1769.

Twigg SM, Cao Z, McLennan SV, Burns WC, Brammar G, Forbes JM \& Cooper ME 2002a Renal connective tissue growth factor induction in experimental diabetes is prevented by aminoguanidine. Endocrinology 143 4907-4915.

Twigg SM, Joly AH, Chen MM, Tsubaki J, Kim HS, Hwa V, Oh Y \& Rosenfeld RG $2002 b$ Connective tissue growth factor/IGFbinding protein-related protein-2 is a mediator in the induction of fibronectin by advanced glycosylation end-products in human dermal fibroblasts. Endocrinology 143 1260-1269.

Wahab NA, Harper K \& Mason RM 1996 Expression of extracellular matrix molecules in human mesangial cells in response to prolonged hyperglycaemia. Biochemical Journal 316 985-992.

Wahab NA, Weston BS, Roberts T \& Mason RM 2002 Connective tissue growth factor and regulation of the mesangial cell cycle: role in cellular hypertrophy. Journal of the American Society of Nephrology 13 2437-2445.

Wandji SA, Gadsby JE, Barber JA \& Hammond JM 2000 Messenger ribonucleic acids for MAC25 and connective tissue growth factor (CTGF) are inversely regulated during folliculogenesis and early luteogenesis. Endocrinology 141 2648-2657.

Wang S, Denichilo M, Brubaker C \& Hirschberg R 2001 Connective tissue growth factor in tubulointerstitial injury of diabetic nephropathy. Kidney International 60 96-105.

Way KJ, Isshiki K, Suzuma K, Yokota T, Zvagelsky D, Schoen FJ, Sandusky GE, Pechous PA, Vlahos CJ, Wakasaki H et al. 2002
Expression of connective tissue growth factor is increased in injured myocardium associated with protein kinase $\mathrm{C}$ beta2 activation and diabetes. Diabetes 51 2709-2718.

Wong M, Kireeva ML, Kolesnikova TV \& Lau LF 1997 Cyr61, product of a growth factor-inducible immediate-early gene, regulates chondrogenesis in mouse limb bud mesenchymal cells. Developmental Biology 192 492-508.

Xie D, Miller CW, O'Kelly J, Nakachi K, Sakashita A, Said JW, Gornbein J \& Koeffler HP 2001a Breast cancer. Cyr61 is overexpressed, estrogen-inducible, and associated with more advanced disease. Journal of Biological Chemistry 276 14187-14194.

Xie D, Nakachi K, Wang H, Elashoff R \& Koeffler HP 2001b Elevated levels of connective tissue growth factor, WISP-1, and CYR61 in primary breast cancers associated with more advanced features. Cancer Research 61 8917-8923.

Yokoi H, Sugawara A, Mukoyama M, Mori K, Makino H, Suganami T, Nagae T, Yahata K, Fujinaga Y, Tanaka I et al. 2001 Role of connective tissue growth factor in profibrotic action of transforming growth factor-beta: a potential target for preventing renal fibrosis. American Journal of Kidney Diseases 38 S134-S138.

Yokoi H, Mukoyama M, Sugawara A, Mori K, Nagae T, Makino H, Suganami T, Yahata K, Fujinaga Y, Tanaka I et al. 2002 Role of connective tissue growth factor in fibronectin expression and tubulointerstitial fibrosis. American Journal of Physiology. Renal Physiology 282 F933-F942.

Zhang R, Averboukh L, Zhu W, Zhang H, Jo H, Dempsey PJ, Coffey RJ, Pardee AB \& Liang P 1998 Identification of rCop-1, a new member of the CCN protein family, as a negative regulator for cell transformation. Molecular and Cellular Biology 18 6131-6141.

Received 28 April 2003

Accepted 22 May 2003 